\title{
NMDA Receptors in Astrocytes
}

DOI:

10.1007/s11064-019-02750-3

\section{Document Version}

Accepted author manuscript

Link to publication record in Manchester Research Explorer

\section{Citation for published version (APA):}

Verkhratsky, A., \& Chvátal, A. (2020). NMDA Receptors in Astrocytes. Neurochemical research, 45(1), 122-133. https://doi.org/10.1007/s11064-019-02750-3

\section{Published in:}

Neurochemical research

\section{Citing this paper}

Please note that where the full-text provided on Manchester Research Explorer is the Author Accepted Manuscript or Proof version this may differ from the final Published version. If citing, it is advised that you check and use the publisher's definitive version.

\section{General rights}

Copyright and moral rights for the publications made accessible in the Research Explorer are retained by the authors and/or other copyright owners and it is a condition of accessing publications that users recognise and abide by the legal requirements associated with these rights.

\section{Takedown policy}

If you believe that this document breaches copyright please refer to the University of Manchester's Takedown Procedures [http://man.ac.uk/04Y6Bo] or contact uml.scholarlycommunications@manchester.ac.uk providing relevant details, so we can investigate your claim.

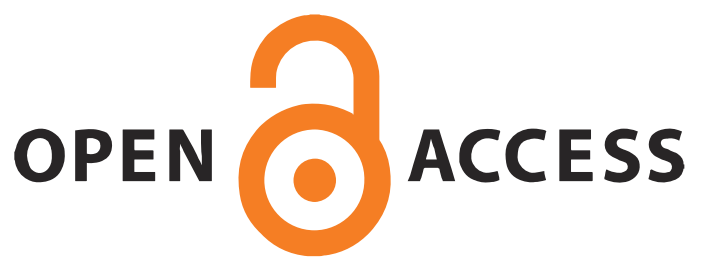




\title{
NMDA receptors in astrocytes
}

\author{
Alexei Verkhratsky ${ }^{1,2,3}$ \& Alexandr Chvátal ${ }^{4,5}$ \\ ${ }^{1}$ Faculty of Biology, Medicine and Health, The University of Manchester, Manchester, \\ M13 9PT, UK; ${ }^{2}$ Achucarro Center for Neuroscience, IKERBASQUE, Basque \\ Foundation for Science, 48011 Bilbao, Spain; ${ }^{3}$ Center for Basic and Translational \\ Neuroscience, Faculty of Health and Medical Sciences, University of Copenhagen, \\ Copenhagen 2200, Denmark; ${ }^{4}$ LBCC Healthcare s.r.o., Prague, Czech Republic; \\ ${ }^{5}$ Institute of Pharmacology and Toxicology, Faculty of Medicine in Plzeň, Charles \\ University; \\ Correspondence: \\ Alexej.Verkhratsky@manchester.ac.uk \\ OR \\ chvatal@fastmail.fm
}




\begin{abstract}
Astrocytes support glutamatergic neurotransmission in the central nervous system through multiple mechanisms which include: (i) glutamate clearance and control over glutamate spillover due to operation of glutamate transporters; (ii) supply of obligatory glutamate precursor glutamine via operation of glutamate-glutamine shuttle; (iii) supply of L-serine, the indispensable precursor of positive NMDA receptors neuromodulator D-serine and (iv) through overall homoeostatic control of the synaptic cleft. Astroglial cells express an extended complement of ionotropic and metabotropic glutamate receptors, which mediate glutamatergic input to astrocytes. In particular a sub-population of astrocytes in the cortex and in the spinal cord express specific type of NMDA receptors assembled from two GluN1, one GluN2C or D and one GluN3 subunits. This composition underlies low $\mathrm{Mg}^{2+}$ sensitivity thus making astroglial NMDA receptors operational at resting membrane potential. These NMDA receptors generate ionic signals in astrocytes and are linked to several astroglial homoeostatic molecular cascades.
\end{abstract}

Key words: astrocyte, neurotransmitters, glutamate, NMDA receptors 


\section{Astrocytes as homoeostatic element of neural networks}

Astroglia represent heterogeneous (Fig. 1) class of neural cells primarily responsible for the homeostatic control $[1 ; 2]$ as well as for defence [3-6] of the central nervous system (CNS). Astrocytes are classified into several subtypes, which include protoplasmic astroglia of the grey matter, fibrous astrocytes of white matter, radial astrocytes (Bergmann glia of cerebellum, Müller glia of the retina, radial glia-like stem cells of the neurogenic niches and tanycytes of hypothalamus), specialised astrocytes such as velate astrocytes, marginal astrocytes, Gomori astrocytes, etc. as well as ependymocytes, choroid plexus cells or retinal pigment epithelial cells (Fig. 1). Despite prominent morphological and functional heterogeneity all astrocytes possess several common features: they are electrically non-excitable, they have highly hyperpolarised (about $-80 \mathrm{mV}$ ) resting membrane potential and they express numerous membrane transporters fundamental for homeostatic support of neural tissue. Although being unable to generate regenerative action potentials, astroglial cellular signalling relies on a complex, spatially and temporally coordinated fluctuations in the intracellular concentrations of ions (most notably $\mathrm{Ca}^{2+}, \mathrm{Na}^{+}$and $\mathrm{Cl}^{-}$ ) ; these ionic fluctiations provide the substrate for astrocyte excitability; often referred to as "ionic" excitability of glia [7-15]. Spatially and temporally coordinated ionic fluxes triggered by neurochemical stimulation or occurring spontaneously regulate functional responses of astrocytes and tune numerous homeostatic cascades expressed in these cells. Astrocytes regulate CNS homeostasis on all levels of CNS organisation from molecular (for example astrocytes control ionostasis and neurotransmitter turnover and catabolism) and cellular (astrocytes support synaptogenesis, synaptic maturation and maintenance, while astroglia like stem cells provide for adult neurogenesis) to organ (astroglia support brain glymphatic system and participates in operation of blood-brain barrier) and systemic (some astrocytes, especially those localised in hypothalamic structures act as chemosensors for oxygen, $\mathrm{CO}_{2}$ or $\mathrm{Na}^{+}$in circulating blood). Astrocytes signal to other cells in the CNS through releasing various types of signalling or neuroactive molecules from neurotransmitters and their precursors to active forms of hormones and pro- or anti-inflammatory factors [16-18]. Astroglial contribution to neurological diseases is multi-faceted ranging from evolutionary conserved protective astrogliosis to astroglial pathological remodelling and astrodegeneration resulting in atrophy and loss of function; to a large extend astroglial responses define the progress and outcome of neuropathologies [3; $19-24]$.

\section{Neurotransmitter receptors in astrocytes}

The first electrophysiological studies of astroglia in the preparations of the brain and the spinal cord or in organotypic brain cultures described these cells as "unresponsive" or even "idle" because they were not able to generate action potentials [25-29]; similarly these cells were not sensitive to major neurotransmitters such as noradrenaline or serotonin. In some of these early observations, however, depolarisation of astrocytes in response to iontophoretic injections or high concentrations of $\gamma$-aminobutiric acid (GABA) or acetylcholine has been noted [28]. Somewhat later depolarisations were recorded from astrocytes in organotypic cultures of medulla oblongata, pons and spinal cord challenged with glutamate and aspartate [30] or with GABA, glycine, $\beta$-alanine and taurine [31]. These electric responses of astrocytes were interpreted either as reflecting activity of ion pumps [28] or as being 
secondary, reflecting release of $\mathrm{K}^{+}$ions from neighbouring neurones activated by neurotransmitters [31]. This latter explanation was very much in line with $\mathrm{K}^{+}$ buffering by astroglia that has been already discovered [32;33], formalised and acknowledged [34; 35].

Establishment of reliable techniques for preparation and maintenance of purified cell cultures of astrocytes and oligodendrocytes [36] allowed electrophysiological studies of glial cells in isolation in the absence of possible interference from other cell types. Direct patch clamp and microelectrode recordings from cultured astrocytes devoid of neuronal contamination, demonstrated functional expression of glutamate, GABA and glycine receptors [37; 38], all of which mediated depolarisation of individual astroglial cells. These initial observations have been promptly confirmed and both whole-cell and single channel ion currents associated with activation of astroglial ionotropic receptors have been characterised biophysically and pharmacologically [39-46]. Slightly later, application of fluorescent $\mathrm{Ca}^{2+}$ recording techniques to cultured astrocytes revealed functional expression of multiple metabotropic G-protein coupled receptors, linked to phospholipase $\mathrm{C}$, production of inositol-,4,5trisphosphate $\left(\mathrm{InsP}_{3}\right)$ and subsequent $\mathrm{InsP}_{3}$-induced $\mathrm{Ca}^{2+}$ release from the endoplasmic reticulum. Operation of this metabotropic pathway has been described and characterised in astrocytes in vitro, in situ and in vivo; with a particular role played by $\mathrm{InsP}_{3}$ receptor type II [47-56]. All in all these experiments have unequivocally demonstrated that astrocytes potentially (i.e in vitro) can express all types of receptors to neurotransmitters, neuromodulators and neurohormones present in the CNS; this expression however is tightly regulated and restricted in vivo [10; 14; 57]. It appeared that the modality of astroglial neurotransmitter receptors is controlled by their immediate neurochemical environment and generally matches the modality of receptors present in their neuronal neighbours. In the cerebellum, for example, receptors expressed in the Bergmann glial cells have the same modality as receptors expressed in the adjacent Purkinje neurone; and these receptors sets are congruent to the neurotransmitters released onto this cellular pair [14]. In the spinal cord, where glycine acts as the major inhibitory neurotransmitter, astrocytes express glycine receptors [58]. Dopamine receptors are expressed in astroglial cells in basal ganglia, whereas astroglial serotonin receptors are usually concentrated near serotonergic terminals.

\section{Astrocytes and glutamatergic transmission}

Synaptic transmission in the CNS is heavily regulated and supported by astrocytes; through the astroglial cradle formed by perisynaptic processes (Fig. 2A) astroglia control synaptogenesis, provide for synaptic isolation, maintenance and contribute to synaptic extinction $[59 ; 60]$. One of the fundamental functions of astroglia is control over the synaptic cleft, which is accomplished by numerous types of solute carrier (SLC) transporters that translocate neurotransmitters and ions, regulate extracellular $\mathrm{pH}$, supply neurones with scavengers of reactive oxygen species, and provide for many more homeostatic supports [2].

Glutamate is the main excitatory neurotransmitter in the CNS of mammals; glutamatergic transmission is fundamental for executive function as well as for higher brain functions, such as learning, memory and cognition. Glutamatergic transmission occurs in specific synapses that contain releasable pool of synaptic vesicles endowed 
with vesicular glutamate transporters VGLUT 1 - 3. These concentrative glutamate transporters driven by $\mathrm{H}^{+}$gradient (established by vacuolar $\mathrm{H}^{+}$ATPase) underlie accumulation of high $(10-100 \mathrm{mM})$ glutamate concentration in the vesicles. Invasion of the action potential and opening of voltage-gated $\mathrm{Ca}^{2+}$ channels in the membrane of presynaptic terminal triggers formation of local $\mathrm{Ca}^{2+}$ microdomains that in turn instigate exocytosis of glutamate-containing synaptic vesicles, which elevates intracleft glutamate to millimolar levels thus activating postsynaptic glutamate receptors $[61 ; 62]$.

The role of astrocytes in maintaining glutamatergic transmission is distinct and fundamental: firstly, astroglial cells remove glutamate from the synaptic cleft thus terminating the neurotransmission and preventing glutamate excitotoxicity; secondly, astroglial perisynaptic processes reach in glutamate transporters prevent glutamate spillover thus providing synaptic isolation and thirdly, astrocytes supply neurones with glutamine, the obligatory precursor for glutamate and GABA (Fig 2B and [2; 63-66]. Glutamate clearance is mediated by glutamate transporters, which are preferentially expressed in astrocytes: the latter are responsible for about $80 \%$ of glutamate removal following physiological neurotransmission. Astrocytes express two types of glutamate transporters classified as EAAT1/SLC1A6 and EAAT2/SLC1A2; both transporters utilise $\mathrm{Na}^{+}$gradient for translocation of glutamate [63]. Anatomically the EAAT1 are predominantly expressed in cerebellum, in the retina and in circumventricular organs [67-69]; the EAAT2 transporters demonstrate higher expression in astrocytes in the rest of the brain. At the ultrastructural level EAAT1/2 are concentrated in perisynaptic astroglial processes [70].

Translocation of a single glutamate molecule by EAAT $1 / 2$ is thermodynamically coupled with co-transport of $3 \mathrm{Na}^{+}$and $1 \mathrm{H}^{+}$and with counter-transport of $1 \mathrm{~K}^{+}$[71; 72]. Glutamate transporters are also associated with thermodynamically uncoupled $\mathrm{Cl}^{-}$ flux through an aqueous pore inbuilt into the transporter molecule [73]. The reversal potential of the transporter ( $\mathrm{E}_{\mathrm{EAAT}}$ ) is determined by transmembrane ion gradients and by concentration of glutamate in the cytosol and in the synaptic cleft [71; 74]. The extracellular concentration of glutamate ranges between $25 \mathrm{nM}$ at rest and $>1 \mathrm{mM}$ at the height of transmission event $[61 ; 75]$ whereas cytosolic glutamate concentration in astrocytes probably does not exceed $0.3-0.5 \mathrm{mM}$ because of a continuous activity of glutamine synthetase [76]. Changes in the concentrations of ions and glutamate affect the $E_{\text {EAAT }}$ in the following manner: 10 fold change in $\left[\mathrm{Na}^{+}\right]_{\mathrm{o}}$ shifts the equilibrium potential by $100 \mathrm{mV}$; whereas 10 -fold changes in $\left[\mathrm{Glu}^{-}\right]_{\mathrm{o}},\left[\mathrm{H}^{+}\right]_{\mathrm{o}}$ and $\left[\mathrm{K}^{+}\right]_{\mathrm{o}}$ shift EEAAT by 31,25 and $-31 \mathrm{mV}$ respectively [71]. In physiological context however the EEAAT is primarily determined by $\left[\mathrm{Glu}^{-}\right]_{\mathrm{o}}$, which increases by $5-6$ orders above resting concentration during synaptic activity; thus at rest the $\mathrm{E}_{\mathrm{EAAT}}$ is $\sim 9 \mathrm{mV}$, whereas at 1 $\mathrm{mM}\left[\mathrm{Glu}^{-}\right]_{\mathrm{o}}$ the EЕAAT is $\sim 145 \mathrm{mV}$. This $\left[\mathrm{Glu}^{-}\right]_{\mathrm{o}}$ dependence ensures that transporter never reverses unless upon terminal failure of ionic homeostasis. The transports velocity of EAAT1/2 is slow with a single cycle requiring $\sim 30 \mathrm{~ms}$ [77].

Astroglial role in supplying neurones with glutamine is again of fundamental importance for neurotransmission, because neurones are incapable of synthesising glutamate; synthesis of glutamate from glucose occurs solely in astrocytes, which specifically express the key enzyme pyruvate carboxylase that produces an obligatory intermediate $\alpha$-ketoglutarate $[65 ; 66 ; 78]$. The second astroglia-specific enzyme fundamental for glutamate catabolism is glutamine synthetase [79; 80], which 
converts glutamate (either synthesised de novo or imported by transporters) into glutamine, a direct precursor of glutamate. In addition glutamine synthetase is critical for detoxifying ammonium $\left(\mathrm{NH}_{4}^{+}\right)$, which is converted into glutamine [81]; of note $\mathrm{NH}_{4}{ }^{+}$is secreted in the course of physiological neurotransmission with subsequent accumulation and conversion in astroglia [82]. Glutamine is exported from astrocytes and redirected to neurones by coordinated $\mathrm{A}$ and $\mathrm{N}$ systems of sodium-coupled neutral amino acid transporters or SNATs; the N system (SNAT3/SLC38A3 and SNAT5/SLC38A5) is present in astrocytes and is tailored for glutamine efflux, whereas the A system (SNAT1/SLC38A1, SNAT2/SLC38A2 and SNAT4/SLC38A4) is expressed in neurones and is tuned for glutamine import [83; 84]. The glutamine entering neurones is deaminated by phosphate activated glutaminase to glutamate thus accomplishing the glutamine-glutamate shuttling. In addition to glutamine astrocytes supply neurones with L-serine, the obligatory precursor for endogenous NMDA receptor positive neuromodulator D-serine $[85 ; 86]$.

\section{Astroglial NMDA receptors}

Functional expression of NMDA receptors in astroglia have been, for a long time, controversial; the NMDA receptors that require depolarization-dependent relief from $\mathrm{Mg}^{2+}$ block and are implicated in synaptic plasticity as coincidence detectors were believed to be expressed exclusively in neurones [87; 88]. These controversies have been addressed and solved in the course of recent two decades, with several lines of evidence indicating presence of fully functional NMDA receptors in astroglia.

\section{Evidence from gene expression}

The first comprehensive transcriptome database for neurones, astrocytes and oligodendrocytes was produced by the group of late Ben Barres [89] in 2008 [90]. A subpopulation of astrocytes bearing enhanced green fluorescence protein expressed under s100B promoter was isolated using fluorescence-activated cell sorting (FACS). Analysis of gene expression demonstrated that astroglial cells, form neonatal as well as young mice express NMDA receptor subunits GluN1, GluN2C, and GluN3A. In astrocytes acutely isolated from cortices of 10,20,30, and 50 days old transgenic mice expressing EGFGP under the control of GFAP promoter (GFAP/EGFP mice) single-cell transcriptome revealed expression of GluN1, GluN2A, GluN2B, GluN2C, GluN2D, and GluN3A receptor subunits [91]. Similarly in primary cultured human astrocytes expression of all seven NMDA receptor subunits (GluN1, GluN2A, GluN2B, GluN2C, GluN2D, GluN3A and GluN3B) has been detected at mRNA and protein levels [92]. Expression of GrinN1-3 genes have been identified in astrocytes isolated form young (2.5 months) and old (15-18 months) mouse astrocytes labelled (for FACS isolation) with fluorescent antibodies for glutamate transporter-1 [93]. In cortical astrocytes isolated based on their expression of EGFP under aldehyde dehydrogenase (Aldh 111) promoter expression of all 7 NMDA receptor subunits was detected $($ GluN2C $($ Grin2c) $>$ GluN3A $($ Grin3a) $>$ GluN1 $($ Grinl) $>$ GluN2B $($ Grin $2 b)>\operatorname{GluN2D}($ Grin2d $)>\operatorname{GluN} 3 \mathrm{~B}($ Grin3b $)>$ GluN2A $($ Grin2a $)$, see [94]).

\section{Structural evidence}

Several immunohistochemical studies have detected presence of NMDA receptors in astroglia. The GluN1 and several GluN2 subunits have been identified at mRNA and 
protein level in cultured or isolated astrocytes [95; 96]. In the basolateral amygdala about $20 \%$ of profiles (revealed by electron microscopy) stained with antibody against GluN1 receptor subunit has been identified as astroglial distal processes [97]. Similarly distal processes and sometimes even somata of adult rat cortical astrocytes were immunopositive for GluN1 and GluN2A/B subunits [98; 99]. Glial distal and perisynaptic processes labelled with GluN1 and GluN2A/B were found in the dorsal cochlear nucleus [100]; GluN1 immunopositive astroglial processes have been detected in the nucleus coeruleus [101] and in the basal nuclei of the amygdala [102]. Using recently developed fluorescent marker model (in which EGFP was linked to GluN2C) astroglial expression of GluN2C subunit has been detected in the cortex, striatum, hippocampus or amygdala but not in the thalamus and basal ganglia [103].

\section{Functional evidence}

The very first electrophysiological recordings of NMDA-induced currents have been performed on cultured and freshly isolated human Müller glial cells. These NMDA currents were sensitive to specific antagonists APV and MK-801, and were somewhat inhibited by $\mathrm{Mg}^{2+}$, although the voltage-dependence of $\mathrm{Mg}^{2+}$ block was shifted towards hyperpolarisation, which allowed receptor activation at resting membrane potential [95]; the NMDA currents were subsequently recorded in parenchymal astrocytes [104; 105]. The NMDA- induced $\mathrm{Ca}^{2+}$ signals (sensitive to NMDA receptor antagonists) have been also monitored from astrocytes in primary culture $[106 ; 107]$ and in acute hippocampal slices from young rats [108]. At the same time in many cells in slice preparation NMDA responses were suppressed by tetrodotoxin suggesting indirect action mediated through neuronal activity [108].

The first in situ electrophysiological recordings of NMDA-receptor mediated ion currents were performed on astrocytes from acutely isolated slices of spinal cord of rats [109]. In these experiments applications of NMDA ( $2 \mathrm{mM})$ induced ion currents in $96 \%$ of all cells studied (Fig. 3); amplitudes of these NMDA currents were, on average, about $50 \mathrm{pA}$. Currents mediated by NMDA receptors is spinal cord astrocytes were insensitive to AMPA/Kainate receptors antagonists and were not modulated by extracellular $\mathrm{Mg}^{2+}$ (Fig. 3). Several years later functional NMDA receptors were identified in astrocytes from cortical slices of wild type and GFAP/EGFP transgenic mice; NMDA at $100 \mu \mathrm{M}$ concentration triggered ion currents in $72 \%$ of all astrocytes examined [110].

The NMDA-activated currents were subsequently recorded from single astrocytes acutely isolated (by employing non-enzymatic vibro-dissection technique) from cortices of GFAP/EGFP transgenic mice $[111 ; 112]$. Challenge of isolated cortical astrocytes with $10 \mu \mathrm{M}$ glutamate triggered the biphasic ion current with distinct pharmacological profile: the fast current component was suppressed by AMPA receptor blocker 6-cyano-7-nitroquinoxaline-2,3-dione (CNQX), whereas the slow component was inhibited by D-2-amino-phosphonopentanoic acid (D-AP5) or dizocilpine (MK-801) (Fig. 4A,B). Application of NMDA alone triggered, in concentration-dependent manner, monophasic currents (Fig. 4C); these NMDAinduced currents were positively modulated by glycine (Fig. 4D) and were inhibited by specific antagonists D-2-amino-phosphonopentanoic acid (D-AP5) and MK-801 ([111]). The voltage-dependence of $\mathrm{Mg}^{2+}$ block was shifted towards hyperpolarisation; with almost $100 \%$ availability of receptors for activation at resting 
membrane potential of $-80 \mathrm{mV}[111 ; 113]$. Astroglial NMDA receptors have intermediate $\mathrm{Ca}^{2+}$ permeability $\left(\mathrm{P}_{\mathrm{Ca}} / \mathrm{P}_{\text {monovalent }} \sim 3\right)$ thus mediating, upon activation, influx of both $\mathrm{Ca}^{2+}$ and $\mathrm{Na}^{+}$[114]. Astroglial NMDA receptors contribute to glial postsynaptic currents triggered by stimulation of neuronal inputs into cortical layer III [111]; the density of astroglial NMDA receptors in mice is age-dependent with maximal expression between 3 and 6 month of age [115].

The precise regional mapping of astrocytes expressing NMDA receptors is yet to be accomplished. In particular, the data on expression of NMDA receptors in astrocytes remain rather controversial. Electrophysiological studies of hippocampal astrocytes in vitro and in situ failed to detect NMDA-induced currents or NMDA-evoked $\mathrm{Ca}^{2+}$ responses $[43 ; 116 ; 117]$. At the same time application of NMDA-glycine mixture to hippocampal astrocytes co-cultured with neurones evoked substantial depolarisation of the former; this depolarisation was suppressed by NMDA receptor antagonist MK801 [118]. This finding was further corroborated in experiments on genetically modified mice, in which NR1 subunit was specifically deleted from astroglial cells. Depolarisation of astrocytes in acute slices isolated from these animals in response to NMDA was significantly reduced compared to the wild type controls [118]. At the same time activation of heuronal NMGA receptors in hippocmpal synapses cases significant $\mathrm{K}^{+}$efflux which instigates astroglial $\mathrm{K}^{+}$buffering associated with $\mathrm{K}^{+}$ inward currents sesnitive to NMDA antagonists [119].

Subunit composition

Astroglial NMDA receptors differ from neuronal ones in their sensitivity to $\mathrm{Mg}^{2+}$ block and in relatively low $\mathrm{Ca}^{2+}$ permeability (for neuronal NMDA receptors $\mathrm{P}_{\mathrm{Ca}} / \mathrm{P}_{\text {monovalent }}$ is around 10 , being thus about 3 times higher [120]). These features reflect specific subunit composition. Astroglial NMDA receptors are sensitive to memantine and the GluNR2C/D subunit-selective antagonist UBP141 [113]; whereas low $\mathrm{Mg}^{2+}$ sensitivity at resting potential arguably indicates the presence of GluNR3 subunit $[121 ; 122]$. In conclusion, the astroglial functional NMDA receptor may therefore be a heterotetramer assembled from two GluN1, one GluN2C or D and one GluN3 subunits [123].

\section{NMDA receptors and astroglial function}

\section{Physiology}

Probably the most obvious function of NMDA receptors is to generate influx of $\mathrm{Na}^{+}$ and $\mathrm{Ca}^{2+}$ for generating ionic signals associated with various glial functions. Indeed activation of NMDA receptors either by application of NMDA or by synaptic stimulation results in $\mathrm{Ca}^{2+}$ signals in both processes and somata of isolated astrocytes and astrocytes in cortical slices (Fig. 5, [114]). The actual mechanisms of this $\mathrm{Ca}^{2+}$ signals could be complex and may reflect direct entry of $\mathrm{Ca}^{2+}$ though NMDA-gated channels or indirect elevation of $\mathrm{Ca}^{2+}$ through, for example, reversed $\mathrm{Na}^{+} / \mathrm{Ca}^{2+}$ exchanger following an increase in cytosolic $\mathrm{Na}^{+}$associated with $\mathrm{Na}^{+}$influx through the NMDA receptor. Of note astroglial NMDA receptors can be activated not only by glutamate but also by mechanical stimulation delivered as fluid shear stress in the absence of agonist [124]. Stimulation of astroglial NMDA receptors may even contribute to heterosynaptic plasticity [118] 
Astroglial NMDA receptors, however, may trigger astroglial $\mathrm{Ca}^{2+}$ signalling in an

alternative and rather peculiar way, by direct link to $\mathrm{Ca}^{2+}$ release from the endoplasmic reticulum (ER) $\mathrm{Ca}^{2+}$ store. It appeared that NMDA triggered $\mathrm{Ca}^{2+}$ signals in rat cortical astrocytes co-cultured with endothelial cells. These NMDA $\mathrm{Ca}^{2+}$ responses were blocked by APV and ifenprodil (the GluN2B antagonist) and were almost completely suppressed by the depletion of the ER [125]. Thus, the possible metabotropic mode of operation of NMDA receptors in astroglia was suggested. This metabotropic pathway was subsequently described in cultured cortical rat astrocytes in which NMDA $\mathrm{Ca}^{2+}$ signals were blocked by inhibitors of the $\mathrm{ER} \mathrm{Ca}^{2+}$ release Xestospognin $\mathrm{C}$ and ryanodine; authors also presented evidence for NMDAdependent mitochondria depolarisation which may be associated with $\mathrm{Ca}^{2+}$ release [126]. The NMDA-evoked $\mathrm{Ca}^{2+}$ responses were found to be sensitive to the inhibition of phospholipase C with U73122 again indicating possible link to a classical $\mathrm{InsP}_{3}$ mediated $\mathrm{Ca}^{2+}$ release pathway [126].

Activation of astroglial NMDA receptors triggered homeostatic astroglial responses; in particular NMDA receptors were reported to couple to antioxidant transcriptional activation nuclear factor-erythroid 2-related factor-2 (Nrf2), which stimulates release of glutathione precursors, thus supporting neuronal glutathione synthesis and boosting antioxidant neuroprotection [127]. Astrocytic NMDA receptors were also shown to stimulate secretion of pro-inflammatory cytokines; this secretion was blocked by memantine [128].

\section{Pathology}

Pathobiological changes of astroglia (manifested in multiple forms from astroglial reactivity to degeneration with loss of function) are indispensable components of neurological diseases $[3 ; 129 ; 130]$. Expression of astrocytic NMDA receptors is generally up-regulated in reactive astrocytes. In hippocampus subjected to transient ischemia astrocytes increased expression of GluN2A and GluN2B subunits; this increase was maximal at 28 days after the lesion [131]. In rat healthy hippocampi the GluN2B subunits were not present in astrocytes; however transient ischemia boosted their expression, which started 3 days after ischaemic attack and reached its maximum in 28 days [132]. Similarly, in vitro, astroglial expression of GluN2B was induced by 5 minutes of anoxia [132]. In mouse primary cultured astrocytes exposed to a medium equilibrated with $85 \% \mathrm{~N} 2$ and $0 \% \mathrm{O} 2$ and lacking glucose and serum expression of GluN1 decreased, while expression of GluN2A and GluN2B demonstrated some increase [133]; this in vitro model however is somewhat difficult to interpret. The upregulation of NMDA receptors in reactive astrocytes could be a part of neuroprotective response associated for example with (already alluded to) NMDAdependent release of glutathione precursors [127].

Activity of NMDA receptors was also found to connect with expression of another important homeostatic astroglial molecule, the inward rectifying $\mathrm{K}_{\mathrm{ir}} 4.1 \mathrm{~K}^{+}$channel critical for physiological $\mathrm{K}^{+}$buffering. Prolonged exposure (3 days) of rat cortical astrocytes to $1 \mathrm{mM}$ glutamate or $100 \mu \mathrm{M}$ NMDA down-regulated astroglial expression of $\mathrm{K}_{\mathrm{ir}} 4.1$ at both mRNA and protein levels; this down-regulation was specifically prevented by NMDA receptor antagonists MK-801 or AP-5 [134]. Very similar down-regulation of astroglial $\mathrm{K}_{\mathrm{in}} 4.1$ channels was observed in the in vivo model of hepatic encephalopathy; expression of $\mathrm{K}_{\mathrm{ir}} 4.1$ was restored by intraperitoneal 
injections of a competitive NMDA receptor antagonist memantine [134]. In addition, long-lasting activation of astroglial NMDA receptors was found to down-regulate expression of glutamine synthetase and aqauporin-4 [135]. Of note, NMDA receptors may also regulate expression of kynurenic acid (powerful endogenous modulator of acetylcholine and glutamate receptors) in astroglia; pharmacological inhibition of astroglial NMDA receptors by memantine facilitated synthesis of kynurenic acid in the context of hepatic encephalopathy [136].

\section{Conclusions}

Astrocytes in different areas of the brain and of the spinal cord express specific type of NMDA receptors characterised by low sensitivity to $\mathrm{Mg}^{2+}$ at resting potential and by relatively low $\mathrm{Ca}^{2+}$ permeability. These biophysical idiosyncrasies arguably reflect specific configuration of astroglial NMDA receptors likely assembled as heterotetramers from $1 \mathrm{GluN1}, 2 \mathrm{GluN} 2$ (C/D?) and $1 \mathrm{GluN} 3$ subunits. Activation of NMDA receptors rigger astroglial $\mathrm{Ca}^{2+}$ and $\mathrm{Na}^{+}$signalling by mediating influx of these ions; there are also indication that NMDA rectors in astrocytes can be coupled to $\mathrm{Ca}^{2+}$ release from the intracellular stores. Astroglial NMDA receptors may contribute to neuropathology; their over-activation can affect astroglial homoeostatic mechanisms. 


\section{References}

1 Verkhratsky A, Nedergaard M (2016) The homeostatic astroglia emerges from evolutionary specialization of neural cells. Philos Trans R Soc Lond B Biol Sci 371 doi:10.1098/rstb.2015.0428

2 Verkhratsky A, Nedergaard M (2018) Physiology of Astroglia. Physiol Rev 98:239-389 doi:10.1152/physrev.00042.2016

$3 \quad$ Pekny $\mathrm{M}$ et al. (2016) Astrocytes: a central element in neurological diseases. Acta Neuropathol 131:323-345 doi:10.1007/s00401-015-1513-1

4 Sofroniew MV (2014) Multiple roles for astrocytes as effectors of cytokines and inflammatory mediators. Neuroscientist 20:160-172 doi:10.1177/1073858413504466

5 Sofroniew MV (2015) Astrocyte barriers to neurotoxic inflammation. Nat Rev Neurosci 16:249-263 doi:10.1038/nrn3898

6 Verkhratsky A, Zorec R, Parpura V (2017) Stratification of astrocytes in healthy and diseased brain. Brain Pathol 27:629-644 doi:10.1111/bpa.12537

$7 \quad$ Kirischuk S, Parpura V, Verkhratsky A (2012) Sodium dynamics: another key to astroglial excitability? Trends Neurosci 35:497-506 doi:10.1016/j.tins.2012.04.003

8 Rose CR, Verkhratsky A (2016) Principles of sodium homeostasis and sodium signalling in astroglia. Glia doi:10.1002/glia.22964

9 Rusakov DA (2015) Disentangling calcium-driven astrocyte physiology. Nat Rev Neurosci 16:226-233 doi:10.1038/nrn3878

10 Verkhratsky A, Orkand RK, Kettenmann H (1998) Glial calcium: homeostasis and signaling function. Physiol Rev 78:99-141

11 Verkhratsky A, Trebak M, Perocchi F, Khananshvili D, Sekler I (2018) Crosslink between calcium and sodium signalling. Exp Physiol 103:157-169 doi:10.1113/EP086534

12 Wilson CS, Mongin AA (2018) The signaling role for chloride in the bidirectional communication between neurons and astrocytes. Neurosci Lett doi:10.1016/j.neulet.2018.01.012

13 Semyanov A (2019) Spatiotemporal pattern of calcium activity in astrocytic network. Cell Calcium 78:15-25

14 Verkhratsky A, Kettenmann H (1996) Calcium signalling in glial cells. Trends Neurosci 19:346-352

15 Deitmer JW, Verkhratsky AJ, Lohr C (1998) Calcium signalling in glial cells. Cell Calcium 24:405-416

16 Verkhratsky A, Matteoli M, Parpura V, Mothet JP, Zorec R (2016) Astrocytes as secretory cells of the central nervous system: idiosyncrasies of vesicular secretion. EMBO J 35:239-257 doi:10.15252/embj.201592705

17 Zorec R, Parpura V, Verkhratsky A (2018) Astroglial vesicular network: evolutionary trends, physiology and pathophysiology. Acta Physiol (Oxf) 222 doi:10.1111/apha.12915

18 Vardjan N, Verkhratsky A, Zorec R (2015) Pathologic potential of astrocytic vesicle traffic: new targets to treat neurologic diseases? Cell Transplant 24:599-612 doi:10.3727/096368915X687750

19 Ferrer I (2017) Diversity of astroglial responses across human neurodegenerative disorders and brain aging. Brain Pathol 27:645-674 doi:10.1111/bpa.12538 
20 Kovacs GG, Lee VM, Trojanowski JQ (2017) Protein astrogliopathies in human neurodegenerative diseases and aging. Brain Pathol 27:675-690 doi:10.1111/bpa.12536

21 Verkhratsky A, Rodriguez JJ, Steardo L (2014) Astrogliopathology: a central element of neuropsychiatric diseases? Neuroscientist 20:576-588 doi: $10.1177 / 1073858413510208$

22 Verkhratsky A, Sofroniew MV, Messing A, deLanerolle NC, Rempe D, Rodriguez JJ, Nedergaard M (2012) Neurological diseases as primary gliopathies: a reassessment of neurocentrism. ASN Neuro 4 doi:10.1042/AN20120010

23 Verkhratsky A, Zorec R, Rodriguez JJ, Parpura V (2016) Astroglia dynamics in ageing and Alzheimer's disease. Curr Opin Pharmacol 26:74-79 doi:10.1016/j.coph.2015.09.011

24 Verkhratsky A, Olabarria M, Noristani HN, Yeh CY, Rodriguez JJ (2010) Astrocytes in Alzheimer's disease. Neurotherapeutics 7:399-412 doi:10.1016/j.nurt.2010.05.017

25 Coombs JS, Eccles JC, Fatt P (1955) The electrical properties of the motoneurone membrane. J Physiol 130:291-325

26 Martin AR, Branch CL (1958) Spontaneous activity of Betz cells in cats with midbrain lesions. J Neurophysiol 21:368-370 doi:10.1152/jn.1958.21.4.368

27 Phillips CG (1956) Intracellular records from Betz cells in the cat. Q J Exp Physiol Cogn Med Sci 41:58-69

28 Krnjevic K, Schwartz S (1967) Some properties of unresponsive cells in the cerebral cortex. Exp Brain Res 3:306-319

29 Hild W, Chang JJ, Tasaki I (1958) Electrical responses of astrocytic glia from the mammalian central nervous system cultivated in vitro. Experientia 14:220221

30 Hosli L, Andres PF, Hosli E (1979) Depolarization of cultured astrocytes by glutamate and aspartate. Neuroscience 4:1593-1598

31 Hosli L, Hosli E, Andres PF, Landolt H (1981) Evidence that the depolarization of glial cells by inhibitory amino acids is caused by an efflux of $\mathrm{K}^{+}$from neurones. Exp Brain Res 42:43-48

32 Hertz L (1965) Possible role of neuroglia: a potassium-mediated neuronal-neuroglial--neuronal impulse transmission system. Nature 206:1091-1094

33 Orkand RK, Nicholls JG, Kuffler SW (1966) Effect of nerve impulses on the membrane potential of glial cells in the central nervous system of amphibia. $\mathrm{J}$ Neurophysiol 29:788-806

34 Kuffler SW (1967) Neuroglial cells: physiological properties and a potassium mediated effect of neuronal activity on the glial membrane potential. Proc R Soc Lond B Biol Sci 168:1-21

35 Somjen GG (1975) Electrophysiology of neuroglia. Annu Rev Physiol 37:163190 doi:10.1146/annurev.ph.37.030175.001115

36 McCarthy KD, de Vellis J (1980) Preparation of separate astroglial and oligodendroglial cell cultures from rat cerebral tissue. J Cell Biol 85:890-902

37 Bowman CL, Kimelberg HK (1984) Excitatory amino acids directly depolarize rat brain astrocytes in primary culture. Nature 311:656-659

38 Kettenmann H, Backus KH, Schachner M (1984) Aspartate, glutamate and gamma-aminobutyric acid depolarize cultured astrocytes. Neurosci Lett 52:2529 
39 Berger T (1995) AMPA-type glutamate receptors in glial precursor cells of the rat corpus callosum: ionic and pharmacological properties. Glia 14:101-114

40 Condorelli DF et al. (1999) Expression and functional analysis of glutamate receptors in glial cells. Adv Exp Med Biol 468:49-67

$41 \quad$ Kettenmann H, Backus KH, Schachner M (1987) $\gamma$-Aminobutyric acid opens $\mathrm{Cl}^{-}$channels in cultured astrocytes. Brain Res 404:1-9

42 Kettenmann H, Schachner M (1985) Pharmacological properties of gammaaminobutyric acid-, glutamate-, and aspartate-induced depolarizations in cultured astrocytes. J Neurosci 5:3295-3301

43 Seifert G, Steinhauser C (1995) Glial cells in the mouse hippocampus express AMPA receptors with an intermediate $\mathrm{Ca}^{2+}$ permeability. Eur J Neurosci 7:1872-1881

44 Steinhauser C, Jabs R, Kettenmann H (1994) Properties of GABA and glutamate responses in identified glial cells of the mouse hippocampal slice. Hippocampus 4:19-35

45 Verkhratsky A, Steinhauser C (2000) Ion channels in glial cells. Brain Res Brain Res Rev 32:380-412

46 Chvatal A, Pastor A, Mauch M, Sykova E, Kettenmann H (1995) Distinct populations of identified glial cells in the developing rat spinal cord slice: ion channel properties and cell morphology. Eur J Neurosci 7:129-142

47 Finkbeiner SM (1993) Glial calcium. Glia 9:83-104 doi:10.1002/glia.440090202

48 Kirischuk S, Tuschick S, Verkhratsky A, Kettenmann H (1996) Calcium signalling in mouse Bergmann glial cells mediated by $\alpha_{1}$-adrenoreceptors and $\mathrm{H}_{1}$ histamine receptors. Eur J Neurosci 8:1198-1208

49 McCarthy KD, Salm AK (1991) Pharmacologically-distinct subsets of astroglia can be identified by their calcium response to neuroligands. Neuroscience 41:325-333

50 Porter JT, McCarthy KD (1995) Adenosine receptors modulate $\left[\mathrm{Ca}^{2+}\right]_{\mathrm{i}}$ in hippocampal astrocytes in situ. JNeurochem 65:1515-1523

51 Kirischuk S, Moller T, Voitenko N, Kettenmann H, Verkhratsky A (1995) ATP-induced cytoplasmic calcium mobilization in Bergmann glial cells. J Neurosci 15:7861-7871

52 Kastritsis CH, Salm AK, McCarthy K (1992) Stimulation of the $\mathrm{P}_{2 \mathrm{Y}}$ purinergic receptor on type 1 astroglia results in inositol phosphate formation and calcium mobilization. JNeurochem 58:1277-1284

53 Verkhratsky A, Rodriguez JJ, Parpura V (2012) Calcium signalling in astroglia. Mol Cell Endocrinol 353:45-56 doi:10.1016/j.mce.2011.08.039

54 Kanemaru K, Kubota J, Sekiya H, Hirose K, Okubo Y, lino M (2013) Calcium-dependent $\mathrm{N}$-cadherin up-regulation mediates reactive astrogliosis and neuroprotection after brain injury. Proc Natl Acad Sci U S A 110:1161211617 doi:10.1073/pnas.1300378110

55 Petravicz J, Boyt KM, McCarthy KD (2014) Astrocyte IP ${ }_{3}$ R2-dependent $\mathrm{Ca}^{2+}$ signaling is not a major modulator of neuronal pathways governing behavior. Front Behav Neurosci 8:384 doi:10.3389/fnbeh.2014.00384

56 Agulhon C, Fiacco TA, McCarthy KD (2010) Hippocampal short- and longterm plasticity are not modulated by astrocyte $\mathrm{Ca}^{2+}$ signaling. Science 327:1250-1254 doi:10.1126/science.1184821

57 Verkhratsky A (2010) Physiology of neuronal-glial networking. Neurochem Int 57:332-343 doi:10.1016/j.neuint.2010.02.002 
58 Pastor A, Chvatal A, Sykova E, Kettenmann H (1995) Glycine- and GABAactivated currents in identified glial cells of the developing rat spinal cord slice. Eur J Neurosci 7:1188-1198

59 Nedergaard M, Verkhratsky A (2012) Artifact versus reality - how astrocytes contribute to synaptic events. Glia 60:1013-1023 doi:10.1002/glia.22288

60 Verkhratsky A, Nedergaard M (2014) Astroglial cradle in the life of the synapse. Philos Trans R Soc Lond B Biol Sci 369:20130595 doi:10.1098/rstb.2013.0595

61 Mayer ML (2011) Structure and mechanism of glutamate receptor ion channel assembly, activation and modulation. Curr Opin Neurobiol 21:283-290 doi:10.1016/j.conb.2011.02.001

62 Sudhof TC, Rizo J (2011) Synaptic vesicle exocytosis. Cold Spring Harb Perspect Biol 3 doi:10.1101/cshperspect.a005637

63 Zhou Y, Danbolt NC (2013) GABA and glutamate transporters in brain. Front Endocrinol (Lausanne) 4:165 doi:10.3389/fendo.2013.00165

64 Danbolt NC (2001) Glutamate uptake. Prog Neurobiol 65:1-105

65 Hertz L, Dringen R, Schousboe A, Robinson SR (1999) Astrocytes: glutamate producers for neurons. J Neurosci Res 57:417-428

66 Schousboe A, Scafidi S, Bak LK, Waagepetersen HS, McKenna MC (2014) Glutamate metabolism in the brain focusing on astrocytes. Adv Neurobiol 11:13-30 doi:10.1007/978-3-319-08894-5_2

67 Lehre KP, Danbolt NC (1998) The number of glutamate transporter subtype molecules at glutamatergic synapses: chemical and stereological quantification in young adult rat brain. J Neurosci 18:8751-8757

68 Rauen T, Rothstein JD, Wassle H (1996) Differential expression of three glutamate transporter subtypes in the rat retina. Cell Tissue Res 286:325-336

69 Berger UV, Hediger MA (2000) Distribution of the glutamate transporters GLAST and GLT-1 in rat circumventricular organs, meninges, and dorsal root ganglia. J Comp Neurol 421:385-399

70 Chaudhry FA, Lehre KP, van Lookeren Campagne M, Ottersen OP, Danbolt $\mathrm{NC}$, Storm-Mathisen J (1995) Glutamate transporters in glial plasma membranes: highly differentiated localizations revealed by quantitative ultrastructural immunocytochemistry. Neuron 15:711-720

71 Zerangue N, Kavanaugh MP (1996) Flux coupling in a neuronal glutamate transporter. Nature 383:634-637 doi:10.1038/383634a0

72 Owe SG, Marcaggi P, Attwell D (2006) The ionic stoichiometry of the GLAST glutamate transporter in salamander retinal glia. J Physiol 577:591599 doi:10.1113/jphysiol.2006.116830

73 Vandenberg RJ, Huang S, Ryan RM (2008) Slips, leaks and channels in glutamate transporters. Channels (Austin) 2:51-58

74 Kirischuk S, Kettenmann H, Verkhratsky A (2007) Membrane currents and cytoplasmic sodium transients generated by glutamate transport in Bergmann glial cells. Pflugers Arch 454:245-252 doi:10.1007/s00424-007-0207-5

75 Herman MA, Jahr CE (2007) Extracellular glutamate concentration in hippocampal slice. J Neurosci 27:9736-9741 doi:10.1523/JNEUROSCI.300907.2007

76 Bramham CR, Torp R, Zhang N, Storm-Mathisen J, Ottersen OP (1990) Distribution of glutamate-like immunoreactivity in excitatory hippocampal pathways: a semiquantitative electron microscopic study in rats. Neuroscience 39:405-417 
77 Otis TS, Kavanaugh MP (2000) Isolation of current components and partial reaction cycles in the glial glutamate transporter EAAT2. J Neurosci 20:27492757

78 Shank RP, Bennett GS, Freytag SO, Campbell GL (1985) Pyruvate carboxylase: an astrocyte-specific enzyme implicated in the replenishment of amino acid neurotransmitter pools. Brain Res 329:364-367

79 Norenberg MD, Martinez-Hernandez A (1979) Fine structural localization of glutamine synthetase in astrocytes of rat brain. Brain Res 161:303-310

80 Rose CF, Verkhratsky A, Parpura V (2013) Astrocyte glutamine synthetase: pivotal in health and disease. Biochem Soc Trans 41:1518-1524 doi:10.1042/BST20130237

81 Cooper AJ, Plum F (1987) Biochemistry and physiology of brain ammonia. Physiol Rev 67:440-519

82 Marcaggi P, Jeanne M, Coles JA (2004) Neuron-glial trafficking of $\mathrm{NH}_{4}{ }^{+}$and $\mathrm{K}^{+}$: separate routes of uptake into glial cells of bee retina. Eur J Neurosci 19:966-976

83 Scalise M, Pochini L, Galluccio M, Indiveri C (2016) Glutamine transport. From energy supply to sensing and beyond. Biochim Biophys Acta doi:10.1016/j.bbabio.2016.03.006

84 Broer S (2014) The SLC38 family of sodium-amino acid co-transporters. Pflugers Arch 466:155-172 doi:10.1007/s00424-013-1393-y

85 Wolosker H, Balu DT, Coyle JT (2016) The rise and fall of the d-serinemediated gliotransmission hypothesis. Trends Neurosci 39:712-721 doi:10.1016/j.tins.2016.09.007

86 Ivanov AD, Mothet JP (2018) The plastic d-serine signaling pathway: Sliding from neurons to glia and vice-versa. Neurosci Lett doi:10.1016/j.neulet.2018.05.039

87 Oca-Balderas PM, González-Hernández JR (2018) NMDA Receptors in Astroglia: Chronology, Controversies, and Contradictions from a Complex Molecule. IntechOpen,

88 Verkhratsky A, Kirchhoff F (2007) NMDA receptors in glia. Neuroscientist 13:28-37 doi:13/1/28 [pii] 10.1177/1073858406294270

89 Butt A, Nedergaard M, Verkhratsky A (2018) Remembering Ben Barres. Neuroglia 1:4-6 doi:10.3390/neuroglia1010002

90 Cahoy JD et al. (2008) A transcriptome database for astrocytes, neurons, and oligodendrocytes: a new resource for understanding brain development and function. J Neurosci 28:264-278 doi:10.1523/JNEUROSCI.4178-07.2008

91 Rusnakova V, Honsa P, Dzamba D, Stahlberg A, Kubista M, Anderova M (2013) Heterogeneity of astrocytes: from development to injury - single cell gene expression. PLoS One 8:e69734 doi:10.1371/journal.pone.0069734

92 Lee MC, Ting KK, Adams S, Brew BJ, Chung R, Guillemin GJ (2010) Characterisation of the expression of NMDA receptors in human astrocytes. PLoS One 5:e14123 doi:10.1371/journal.pone.0014123

93 Orre $\mathrm{M}$ et al. (2014) Acute isolation and transcriptome characterization of cortical astrocytes and microglia from young and aged mice. Neurobiol Aging 35:1-14 doi:10.1016/j.neurobiolaging.2013.07.008

94 Zhang Y et al. (2014) An RNA-sequencing transcriptome and splicing database of glia, neurons, and vascular cells of the cerebral cortex. J Neurosci 34:11929-11947 doi:10.1523/JNEUROSCI.1860-14.2014 
95 Puro DG, Yuan JP, Sucher NJ (1996) Activation of NMDA receptor-channels in human retinal Muller glial cells inhibits inward-rectifying potassium currents. Vis Neurosci 13:319-326

96 Lopez T, Lopez-Colome AM, Ortega A (1997) NMDA receptors in cultured radial glia. FEBS Lett 405:245-248

97 Gracy KN, Pickel VM (1995) Comparative ultrastructural localization of the NMDAR1 glutamate receptor in the rat basolateral amygdala and bed nucleus of the stria terminalis. J Comp Neurol 362:71-85 doi:10.1002/cne.903620105

98 Conti F, DeBiasi S, Minelli A, Melone M (1996) Expression of NR1 and NR2A/B subunits of the NMDA receptor in cortical astrocytes. Glia 17:254258 doi:10.1002/(SICI)1098-1136(199607)17:3\&1t;254::AIDGLIA7\&gt;3.0.CO;2-0

99 Conti F, Barbaresi P, Melone M, Ducati A (1999) Neuronal and glial localization of NR1 and NR2A/B subunits of the NMDA receptor in the human cerebral cortex. Cereb Cortex 9:110-120

100 Petralia RS, Wang YX, Zhao HM, Wenthold RJ (1996) Ionotropic and metabotropic glutamate receptors show unique postsynaptic, presynaptic, and glial localizations in the dorsal cochlear nucleus. J Comp Neurol 372:356-383 doi:10.1002/(SICI)1096-9861(19960826)372:3\&1t;356::AIDCNE3\&gt;3.0.CO;2-1

101 Van Bockstaele EJ, Colago EE (1996) Selective distribution of the NMDA-R1 glutamate receptor in astrocytes and presynaptic axon terminals in the nucleus locus coeruleus of the rat brain: an immunoelectron microscopic study. $\mathrm{J}$ Comp Neurol 369:483-496 doi:10.1002/(SICI)10969861(19960610)369:4\&1t;483::AID-CNE1\&gt;3.0.CO;2-0

102 Farb CR, Aoki C, Ledoux JE (1995) Differential localization of NMDA and AMPA receptor subunits in the lateral and basal nuclei of the amygdala: a light and electron microscopic study. J Comp Neurol 362:86-108 doi:10.1002/cne.903620106

103 Ravikrishnan A, Gandhi PJ, Shelkar GP, Liu J, Pavuluri R, Dravid SM (2018) Region-specific Expression of NMDA Receptor GluN2C Subunit in Parvalbumin-Positive Neurons and Astrocytes: Analysis of GluN2C Expression using a Novel Reporter Model. Neuroscience 380:49-62 doi:10.1016/j.neuroscience.2018.03.011

104 Nishizaki T, Matsuoka T, Nomura T, Kondoh T, Tamaki N, Okada Y (1999) Store $\mathrm{Ca}^{2+}$ depletion enhances NMDA responses in cultured human astrocytes. Biochem Biophys Res Commun 259:661-664

105 Kondoh T, Nishizaki T, Aihara H, Tamaki N (2001) NMDA-responsible, APV-insensitive receptor in cultured human astrocytes. Life Sci 68:1761-1767

106 Zhang Q, Hu B, Sun S, Tong EMS (2003) Induction of increased intracellular calcium in astrocytes by glutamate through activating NMDA and AMPA receptors. J Huazhong UnivSci Techn 23:254-257

$107 \mathrm{Hu}$ B, Sun SG, Tong ET (2004) NMDA and AMPA receptors mediate intracellular calcium increase in rat cortical astrocytes. Acta Pharmacol Sin 25:714-720

108 Porter JT, McCarthy KD (1995) GFAP-positive hippocampal astrocytes in situ respond to glutamatergic neuroligands with increases in [Ca2+]i. Glia 13:101112 doi:10.1002/glia.440130204 
109 Ziak D, Chvatal A, Sykova E (1998) Glutamate-, kainate- and NMDA-evoked membrane currents in identified glial cells in rat spinal cord slice. Physiol Res 47:365-375

110 Schipke CG, Ohlemeyer C, Matyash M, Nolte C, Kettenmann H, Kirchhoff F (2001) Astrocytes of the mouse neocortex express functional N-methyl-Daspartate receptors. Faseb J 15:1270-1272

111 Lalo U, Pankratov Y, Kirchhoff F, North RA, Verkhratsky A (2006) NMDA receptors mediate neuron-to-glia signaling in mouse cortical astrocytes. J Neurosci 26:2673-2683

112 Kirchhoff F (2017) Analysis of Functional NMDA Receptors in Astrocytes. Methods Mol Biol 1677:241-251 doi:10.1007/978-1-4939-7321-7_13

113 Palygin O, Lalo U, Pankratov Y (2011) Distinct pharmacological and functional properties of NMDA receptors in mouse cortical astrocytes. $\mathrm{Br} \mathrm{J}$ Pharmacol 163:1755-1766 doi:10.1111/j.1476-5381.2011.01374.x

114 Palygin O, Lalo U, Verkhratsky A, Pankratov Y (2010) Ionotropic NMDA and $\mathrm{P} 2 \mathrm{X} 1 / 5$ receptors mediate synaptically induced $\mathrm{Ca} 2+$ signalling in cortical astrocytes. Cell Calcium 48:225-231 doi:10.1016/j.ceca.2010.09.004

115 Lalo U, Palygin O, North RA, Verkhratsky A, Pankratov Y (2011) Agedependent remodelling of ionotropic signalling in cortical astroglia. Aging Cell 10:392-402 doi:10.1111/j.1474-9726.2011.00682.x

116 Cai Z, Kimelberg HK (1997) Glutamate receptor-mediated calcium responses in acutely isolated hippocampal astrocytes. Glia 21:380-389

117 Shelton MK, McCarthy KD (1999) Mature hippocampal astrocytes exhibit functional metabotropic and ionotropic glutamate receptors in situ. Glia 26:111

118 Letellier M, Park YK, Chater TE, Chipman PH, Gautam SG, Oshima-Takago T, Goda Y (2016) Astrocytes regulate heterogeneity of presynaptic strengths in hippocampal networks. Proc Natl Acad Sci U S A 113:E2685-2694 doi:10.1073/pnas.1523717113

119 Shih PY et al. (2013) Retrograde synaptic signaling mediated by K+ efflux through postsynaptic NMDA receptors. Cell Rep 5:941-951 doi:10.1016/j.celrep.2013.10.026

120 Pankratov Y, Lalo U, Krishtal OA, Verkhratsky A (2009) P2X receptors and synaptic plasticity. Neuroscience 158:137-148 doi:10.1016/j.neuroscience.2008.03.076

121 Chatterton JE et al. (2002) Excitatory glycine receptors containing the NR3 family of NMDA receptor subunits. Nature 415:793-798 doi:10.1038/nature715

122 Tong G et al. (2008) Modulation of NMDA receptor properties and synaptic transmission by the NR3A subunit in mouse hippocampal and cerebrocortical neurons. J Neurophysiol 99:122-132 doi:10.1152/jn.01044.2006

123 Lalo U, Pankratov Y, Parpura V, Verkhratsky A (2011) Ionotropic receptors in neuronal-astroglial signalling: what is the role of "excitable" molecules in nonexcitable cells. Biochim Biophys Acta 1813:992-1002 doi:10.1016/j.bbamcr.2010.09.007

124 Maneshi MM, Maki B, Gnanasambandam R, Belin S, Popescu GK, Sachs F, Hua SZ (2017) Mechanical stress activates NMDA receptors in the absence of agonists. Sci Rep 7:39610 doi:10.1038/srep39610 
125 Gerard F, Hansson E (2012) Inflammatory activation enhances NMDAtriggered $\mathrm{Ca} 2+$ signalling and IL-1beta secretion in primary cultures of rat astrocytes. Brain Res 1473:1-8 doi:10.1016/j.brainres.2012.07.032

126 Montes de Oca Balderas P, Aguilera P (2015) A Metabotropic-Like FluxIndependent NMDA Receptor Regulates Ca2+ Exit from Endoplasmic Reticulum and Mitochondrial Membrane Potential in Cultured Astrocytes. PLoS One 10:e0126314 doi:10.1371/journal.pone.0126314

127 Jimenez-Blasco D, Santofimia-Castano P, Gonzalez A, Almeida A, Bolanos JP (2015) Astrocyte NMDA receptors' activity sustains neuronal survival through a Cdk5-Nrf2 pathway. Cell Death Differ 22:1877-1889 doi:10.1038/cdd.2015.49

128 Suhs KW, Gudi V, Eckermann N, Fairless R, Pul R, Skripuletz T, Stangel M (2016) Cytokine regulation by modulation of the NMDA receptor on astrocytes. Neurosci Lett 629:227-233 doi:10.1016/j.neulet.2016.07.016

129 Verkhratsky A, Parpura V (2016) Astrogliopathology in neurological, neurodevelopmental and psychiatric disorders. Neurobiol Dis 85:254-261 doi:10.1016/j.nbd.2015.03.025

130 Verkhratsky A, Steardo L, Parpura V, Montana V (2016) Translational potential of astrocytes in brain disorders. Prog Neurobiol 144:188-205 doi:10.1016/j.pneurobio.2015.09.003

131 Gottlieb M, Matute C (1997) Expression of ionotropic glutamate receptor subunits in glial cells of the hippocampal CA1 area following transient forebrain ischemia. J Cereb Blood Flow Metab 17:290-300 doi:10.1097/00004647-199703000-00006

132 Krebs C, Fernandes HB, Sheldon C, Raymond LA, Baimbridge KG (2003) Functional NMDA receptor subtype $2 \mathrm{~B}$ is expressed in astrocytes after ischemia in vivo and anoxia in vitro. $\mathrm{J}$ Neurosci 23:3364-3372

133 Zhou Y et al. (2010) Astrocytes express N-methyl-D-aspartate receptor subunits in development, ischemia and post-ischemia. Neurochem Res 35:2124-2134 doi:10.1007/s11064-010-0325-x

134 Obara-Michlewska M, Ruszkiewicz J, Zielinska M, Verkhratsky A, Albrecht J (2015) Astroglial NMDA receptors inhibit expression of Kir4.1 channels in glutamate-overexposed astrocytes in vitro and in the brain of rats with acute liver failure. Neurochem Int 88:20-25 doi:10.1016/j.neuint.2014.10.006

135 Skowronska K, Obara-Michlewska M, Czarnecka A, Dabrowska K, Zielinska M, Albrecht J (2018) Persistent Overexposure to N-Methyl-D-Aspartate (NMDA) Calcium-Dependently Downregulates Glutamine Synthetase, Aquaporin 4, and Kir4.1 Channel in Mouse Cortical Astrocytes. Neurotox Res doi:10.1007/s12640-018-9958-3

136 Obara-Michlewska M, Tuszynska P, Albrecht J (2013) Ammonia upregulates kynurenine aminotransferase II mRNA expression in rat brain: a role for astrocytic NMDA receptors? Metab Brain Dis 28:161-165 doi:10.1007/s11011-012-9353-3 


\section{Figure legends}

Figure 1. Classification of astroglia

Figure 2. Astrocytes in glutamatergic neurotransmission.

A: The concept of astroglial cradle. Synapses in the brain and in the spinal cord are composed of several components that include the presynaptic terminal the postsynaptic part and the perisynaptic process of the astrocyte. Astroglial perisynaptic sheath enwraps synaptic structures and regulate, influence and assist synaptogenesis, synaptic maturation, synaptic maintenance and synaptic extinction. Modified from [60].

B: Astrocytes support and regulate glutamatergic neurotransmission. Astrocytes are central component of glutamate-glutamine shuttle; glutamate taken up through glutamate transporters or synthesised de novo from glucose is converted to glutamine; glutamine is translocated to the neurone via $\mathrm{N}$ and A system of SNAT transporters. After entering neuronal terminal glutamine is converted into glutamate and accumulated into synaptic vesicles. Astrocytes also provide neurones with L-serine, an obligatory precursor for NMDA receptor endogenous positive modulator D-serine.

Figure 3. NMDA receptors mediated currents in astrocytes from rat spinal cord slices.

A: Membrane currents recorded from an astrocyte in acute spinal cord slice. The membrane was clamped for $50 \mathrm{~ms}$ to increasing de- and hyperpolarizing potentials ranging from $-160 \mathrm{mV}$ to $+20 \mathrm{mV}$ with $10 \mathrm{mV}$ increment, which revealed classical passive electrophysiological signature of an astroglial cell.

B: Representative traces demonstrating ion current evoked by application of $2 \mathrm{mM}$ NMDA.

C: NMDA ( $2 \mathrm{mM})$-evoked current was not blocked by CNQX $(100 \mu \mathrm{M})$ in contrast to kainate-evoked inward current recorded from the same cell.

D. E: Neither 5 min preincubation with $\mathrm{Ca}^{2+}$-free media, nor 5 minutes preincubation with $3 \mathrm{mM}$ of $\mathrm{Mg}^{2+}$ significantly affected NMDA-evoked inward currents.

Membrane currents (B - E) were recorded in dorsal horn of P6-7 animals at a holding potential of $-70 \mathrm{mV}$.

Modified from [109]

Figure 4. NMDA receptor-mediated currents in cortical astrocytes.

A: NBQX inhibits the fast component of glutamate-induced current. Representative traces illustrate the current before, during and after application of $30 \mu \mathrm{M} \mathrm{NBQX}$ (left panel), and the NBQX-sensitive current obtained by subtraction (right panel). The concentration-dependence of the block of the fast component for four cells $\left(\mathrm{IC}_{50}=2.2\right.$ $\pm 0.4 \mu \mathrm{M}$, Hill coefficient $=1.9$ ) is shown in the inset. 
B: D-AP5 inhibits the slow component of glutamate-induced current. Representative traces demonstrating the effect of $1 \mu \mathrm{M}$ D-AP5 (left panel) and the D-AP5-sensitive component obtained by subtraction (right panel). The concentration-dependence of the block for five cells $\left(\mathrm{IC}_{50}=0.64 \pm 0.1 \mu \mathrm{M}\right.$, Hill coefficient $\left.=1.6\right)$ in the inset.

$\mathrm{C}$ : NMDA-induced ( $2 \mathrm{~s}$ application) currents in a single astrocyte and concentrationresponse curve constructed from six such experiments $\left(\mathrm{EC}_{50} 0.34 \pm 0.06 \mu \mathrm{M}\right.$, Hill coefficient $=1.5$ ).

D: Glycine-dependent potentiation of astrocyte NMDA response. NMDA-induced currents in glycine-free normal extracellular solution are shown on the top; NMDAinduced currents in the presence of different glycine concentrations $(30 \mathrm{nM}, 1 \mu \mathrm{M}, 10$ $\mu \mathrm{M}$ and $30 \mu \mathrm{M})$ are displayed below. The concentration-response curve $\left(\Delta \mathrm{I}_{\text {norm }}\right.$ represents the amplitudes of current increase normalised to the maximal increase at 30 $\mu \mathrm{M}$ glycine) constructed from seven experiments is shown on the right $\left(\mathrm{EC}_{50} 1.1 \pm\right.$ $0.07 \mu \mathrm{M}$, Hill coefficient $=1.2$ ).

Reproduced with permission from [111].

Figure 5. NMDA-receptor mediated $\mathrm{Ca}^{2+}$ signalling in astrocytes in vitro and in situ.

A: NMDA receptor-mediated $\mathrm{Ca}^{2+}$-signalling in cortical astrocytes isolated from GFAP/EGFP mice. Acutely isolated astrocytes were loaded with Fluo-4 via a patch pipette. Fluorescent images were recorded simultaneously with transmembrane currents evoked by application of $30 \mu \mathrm{M}$ NMDA' $\left[\mathrm{Ca}^{2+}\right]_{i}$ transients are represented as the $\Delta \mathrm{F} / \mathrm{F}_{0}$ ratio averaged over the cell soma. Holding potential was $-80 \mathrm{mV}$.

On the top the images of Fluo-4 loaded astrocyte at rest (left) and EGFP fluorescence image from the same cell taken prior to the establishment of whole-cell configuration. Bottom panel shows Fluo-4 image of the cell at the peak of the response; representative $\left[\mathrm{Ca}^{2+}\right]_{i}$ transient and membrane current are shown on the right.

B: Cortical layer II astrocytes were loaded with Fura-2 in situ via patch pipette. Fluorescent images were recorded simultaneously with glial currents evoked by neuronal afferent stimulation (single stimuli or high-frequency (HFS) stimulation) in presence of CNQX (control) and after application of $30 \mu \mathrm{M}$ D-AP5. Representative images (pseudo-colour, pipette image subtracted) are shown on the left and glial synaptic currents on the right.

Reproduced with permission from [114]. 


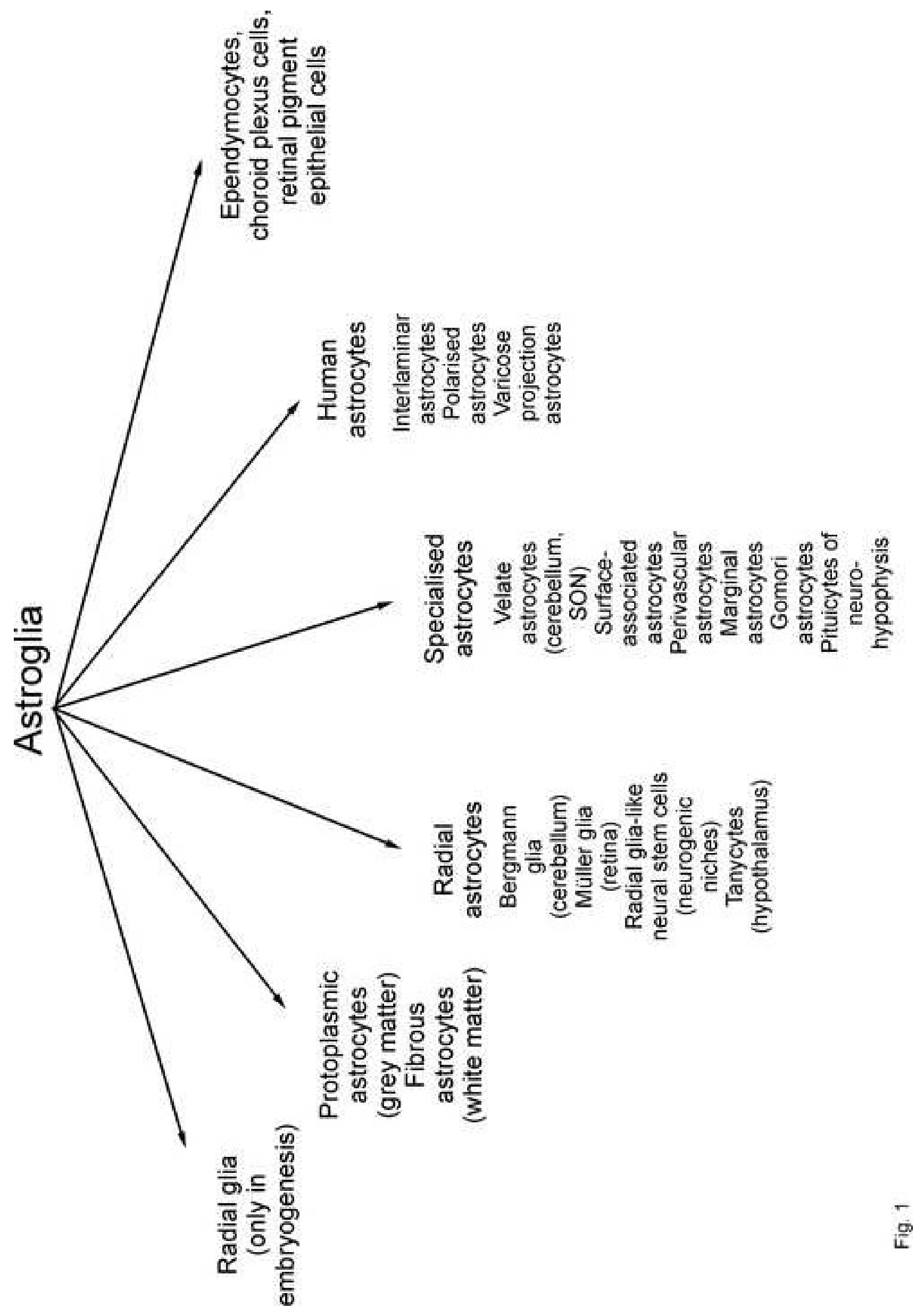


A

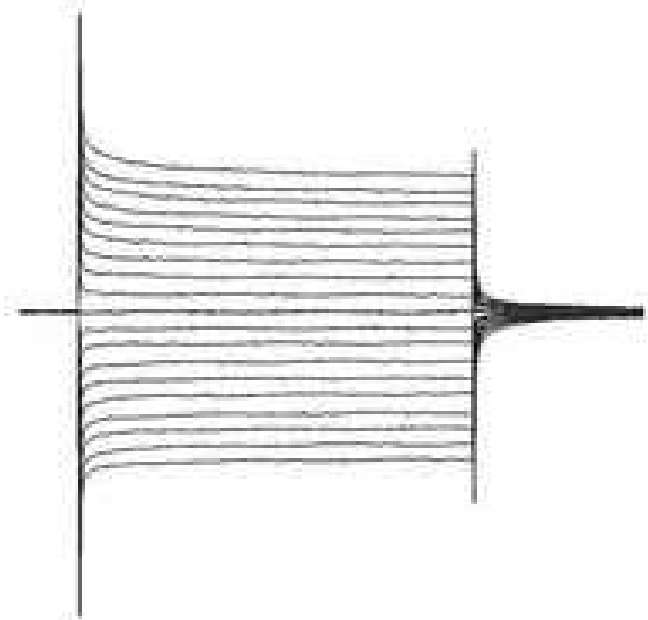

C

$\mathrm{NMDA}+\mathrm{CNQX}$

D

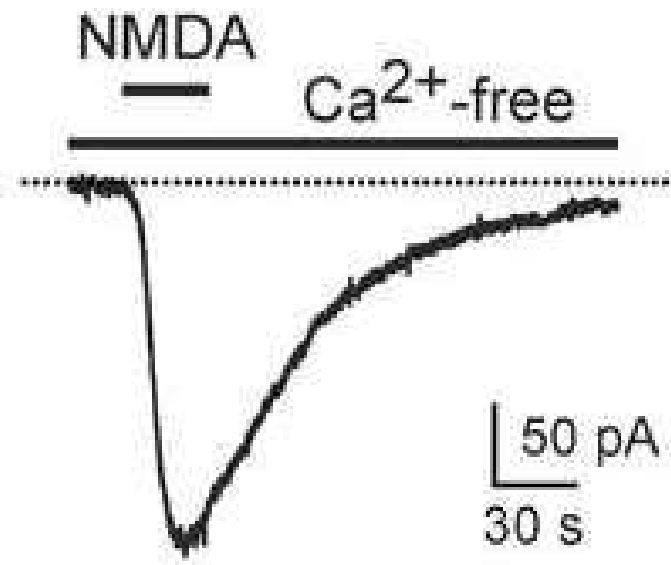

B

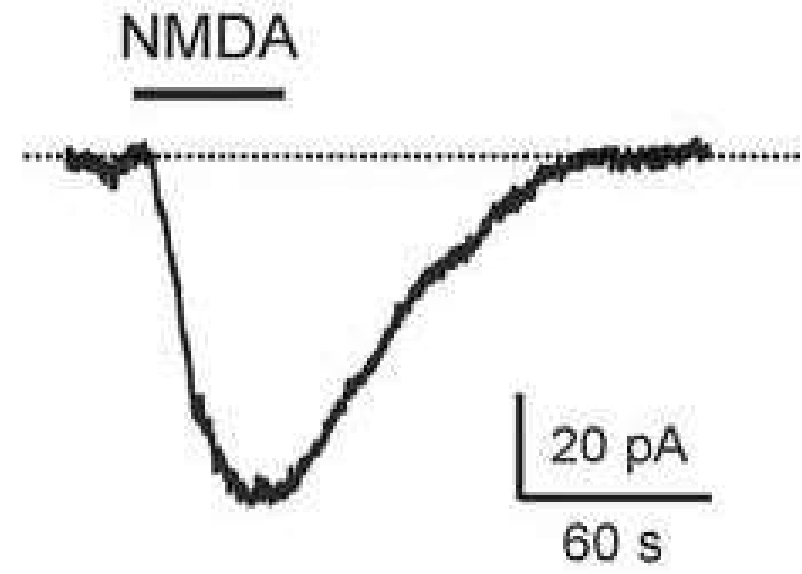

kainate + CNQX

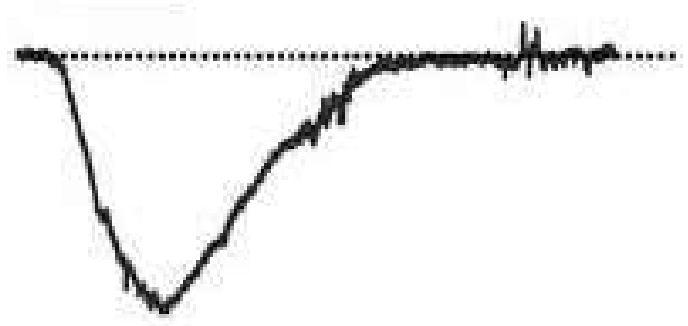

$E$

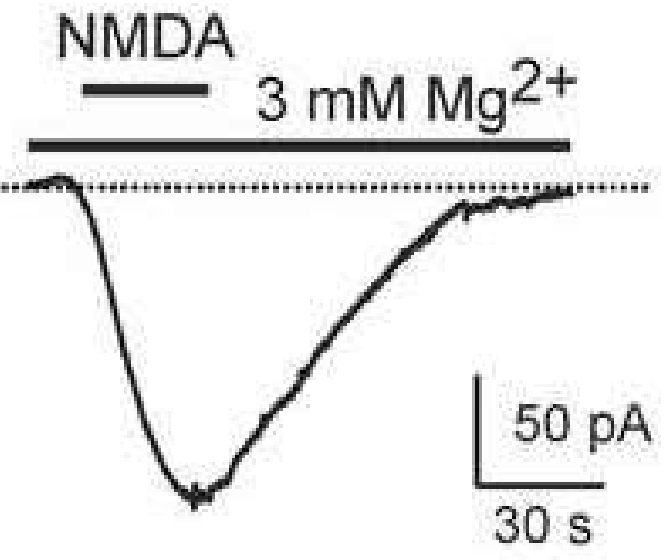

Fig. 3 

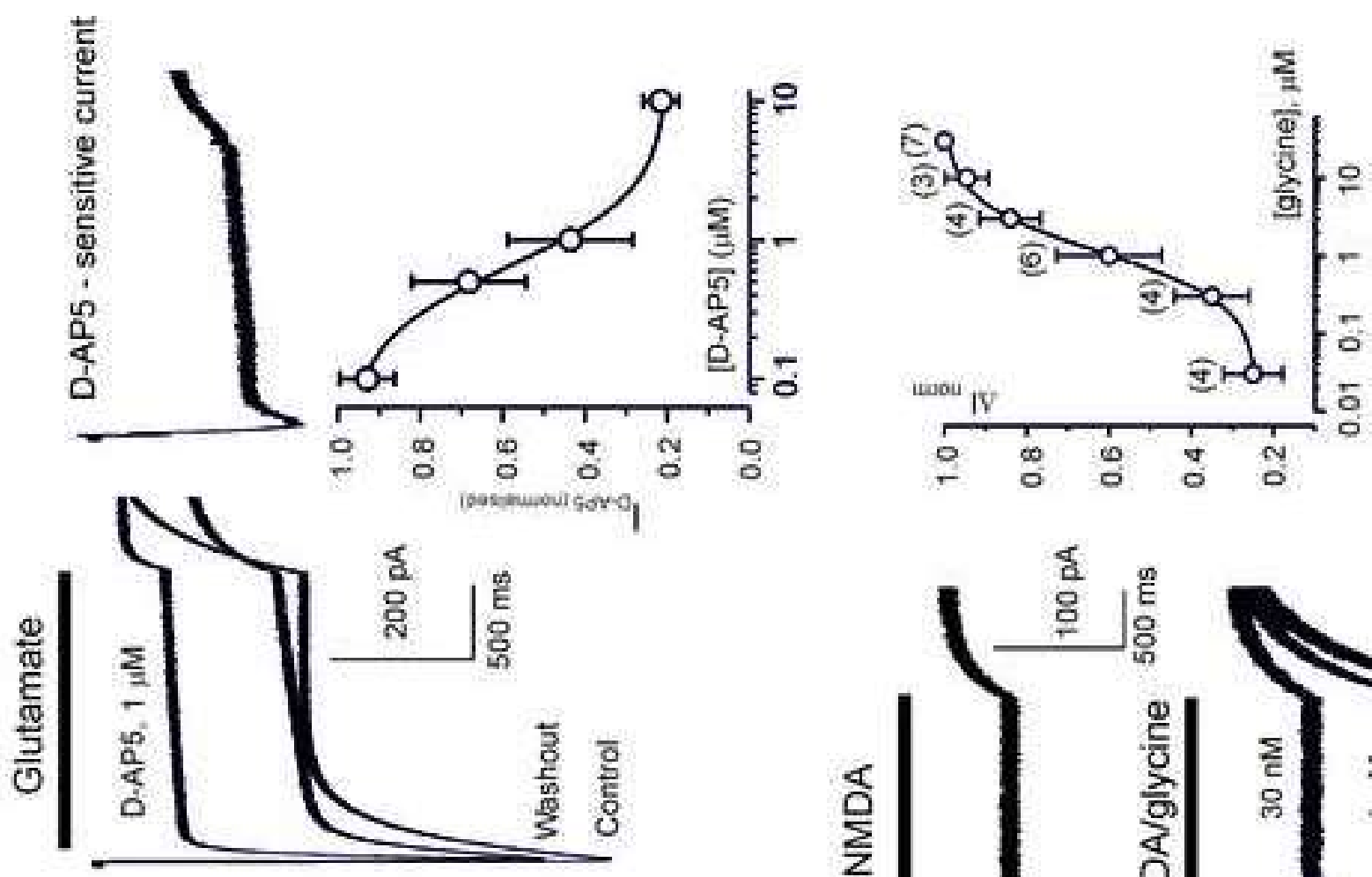

$\infty$
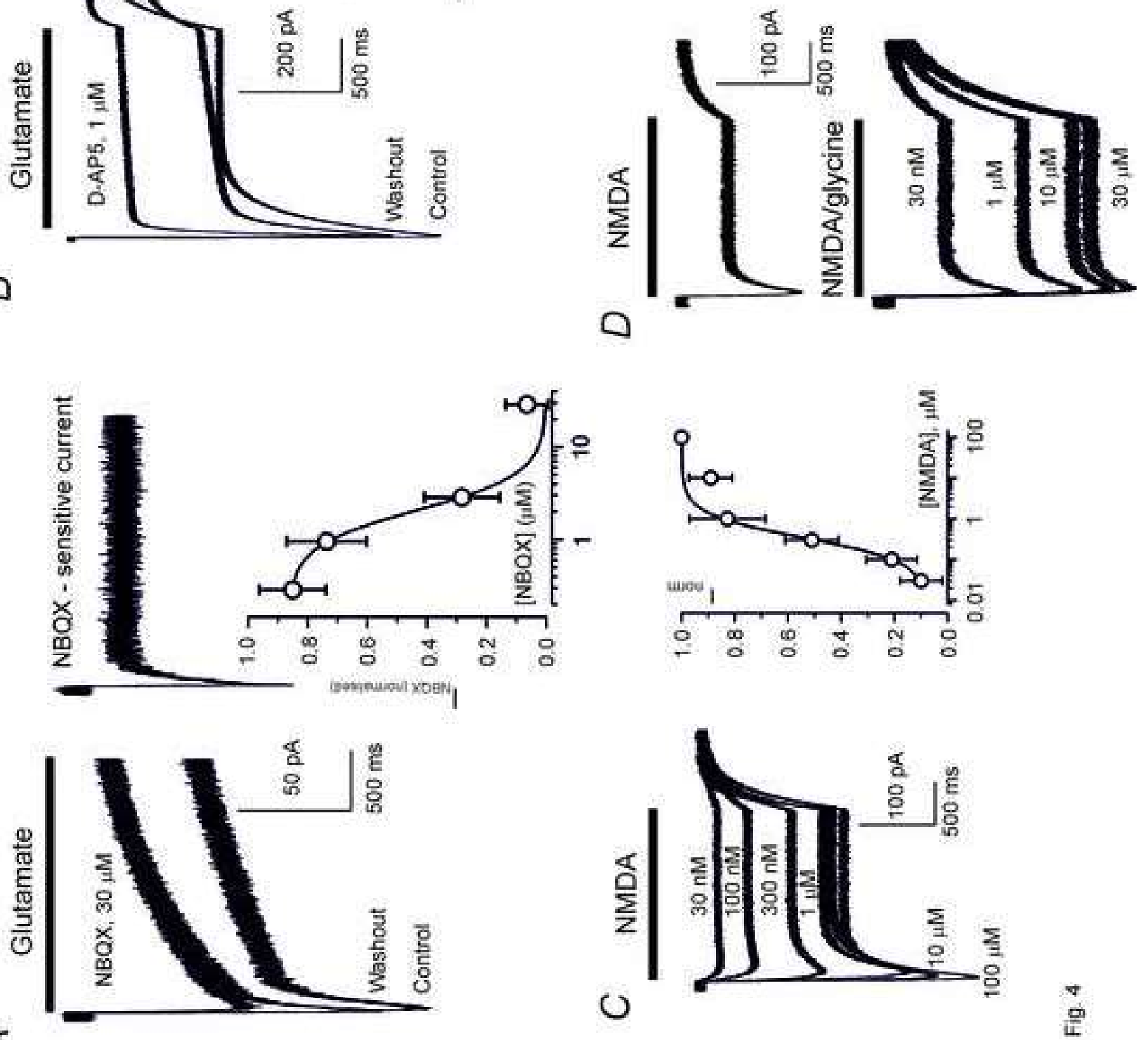

문 

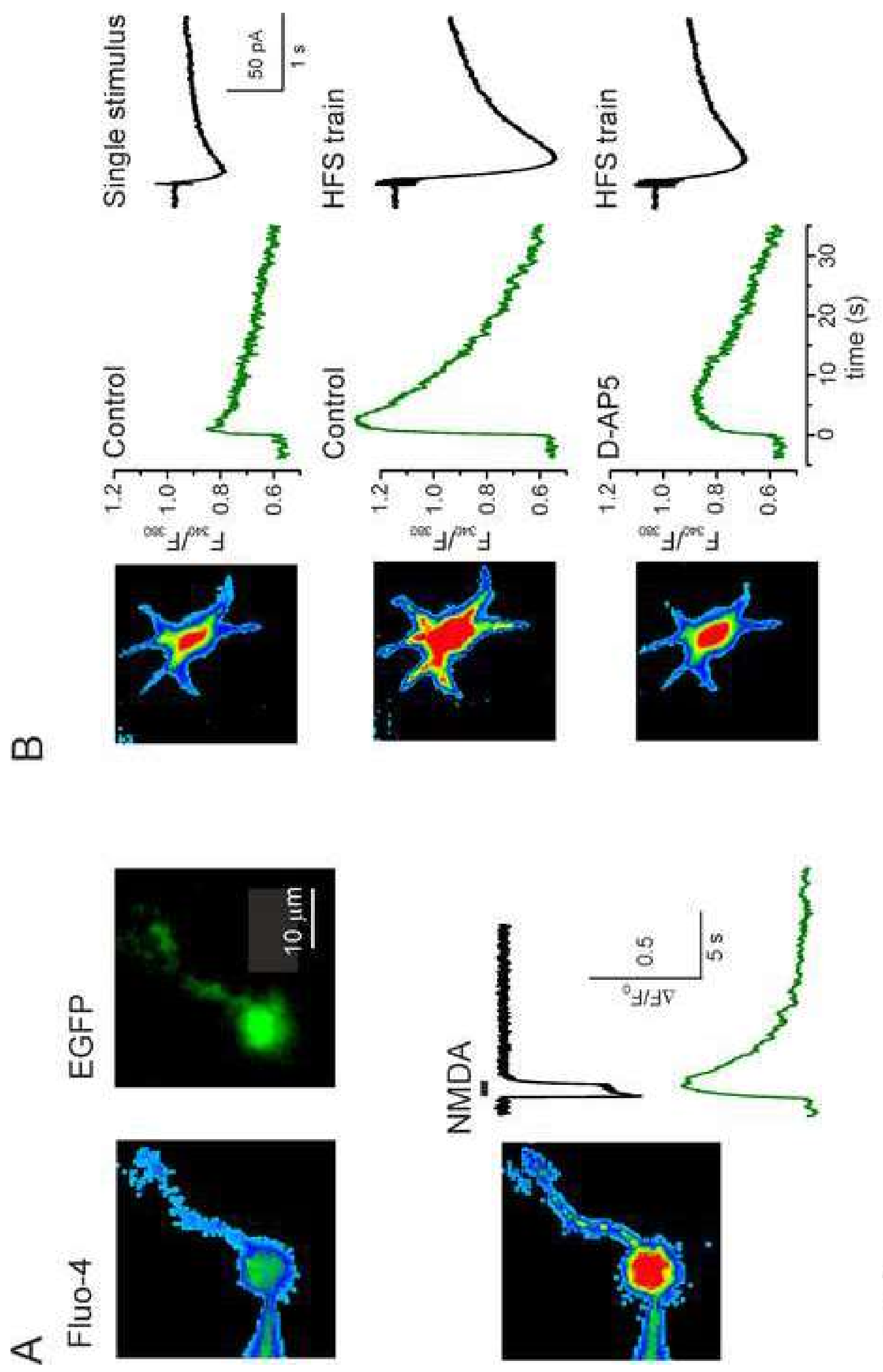

ำ 
Click here to access/download Supplementary material NMDA_Chvatal_REVISED_FINAL_marked.doc 